\title{
Analysis of Feminist Principels in The Da'wah Agenda of Gender Equality
}

\author{
Karimuddin Nasution \\ karimuddin619@gmail.com \\ The National University of Malaysia \\ Mohd Faizulamri Mohd Saad \\ faizam@ukm.edu.my \\ The National University of Malaysia
}

\begin{abstract}
One of the da'wah that is quite intense this time in the media is the da'wah feminist group for gender equality. The main mission of Muslim feminists is to equalize men and women in all matters. To fulfill this mission, they always lay down the basic principles of gender equality taken from the Koran and the hadith, then they will interpret textually. Only after that was reached did they interpret the Koran and the Hadith in accordance with their wishes. If it contradicts the verses that place men and women differently they will usually deny it on the grounds that it conflicts with the principle of gender equality. This study aims to analyze the principles of gender equality in the gender equality da'wah agenda. Methodology of this study was qualitative using document analysis. Data collection was done through library research. The data were analyzed using descriptive, comparative and critique. The findings showed that the feminists made Qur'anic verses as the principles of gender equality. The principles are men and women alike servants, men and women alike caliphs, men and women alike accept the covenant when they are in the womb, Adam and Eve are both engaged in transgression in heaven until had been sent to the earth, men and women equally have potential in every aspect of life. The Qur'anic verses that are made as the basis of the principles of gender equality seem to be over-implemented. The tafsir scholars do not explain the verses in the context of male and female relationships. The implication of this study is that Muslims are encouraged to refer to the interpretation of the authority scholars who have been recognized by the Muslim's world, therefore is no mistakes in understanding the verses of the Qur'an. It is also expected to give a real understanding of the relationship between men and women in the Qur'an.
\end{abstract}

Keywords: gender; feminist; da'kwah agenda; gender equality; principle of Quranic verses

\section{INTRODUCTION}

Gender is a term commonly used to describe the relationship between men and women. The word 'gender' comes from the English language, derived from the French old vocabulary of gendre which means kind, genus, and style. There is also other sources from Spanish gener means race and kind (Walter 1993; Kluge \& Lutz 2008). The word gender is also referred to sex (M. Echols \& Shadily 1983). Gender can also be defined as differences between male and female because of cultural constructs and cultural expectations for women and men (M. Lips 1993). 
The discourse of gender equality was not originated from Islam, it came from the West in the mid- $19^{\text {th }}$ century. This concept is evolving in Europe and America, it expanded rapidly until it grew into Islamic religion. The Islamic religion which made the Qur'an as the main reference, is very concerned with the concept of equality and equilibrium. The equilibrium pattern not only regulated relationships between humans, but also regulated human relationships (microcosm), nature (macrocosm) and God (Zaitunah 2015).

When gender discourse expanded to the Islamic world, gender equality interpretation was started to exist. The classical interpretations were criticized by Muslim feminists because of gender bias. Meanwhile, Islam was sent to free people from all forms of injustice and discrimination, including discrimination in the relationship between men and women. Thus, if there is an understanding that is not parallel with the main purpose of Islam, it is necessary for them to review and make new interpretations which is same with the ideals of Islam (MusdahMulia 2011).

According to the feminists, negative attitudes towards women have been common among Muslims. It came from a theological point of view from the Qur'an and Hadith. According to them, male equality with women cannot be established, except by reviewing the Qur'an and Hadith (Kadarussman, 2005).

According to Musdah (2014), in Islam, there was a term of nas, which referred to the Qur'an and the Hadith of the Prophet and there was a term of exegesis, which defined as the understanding of the scholars of the Qur'an and Hadith. According to her, the Qur'anic and Hadith verses are static while the interpretation is dynamic. Therefore, if someone is asked either Islamic teachings are unfair to women or not? According to Musdah, if referred to the Qur'an and Hadith, the answer is "No, Islamic law is fair". However, if referred to the interpretation, then the answer is "Yes, it is not fair".

Based on the above justifications, new interpretations were showed up especially on the verses related to gender in the Qur'an as being done by Amina Wadud, Azra Asghar Ali, Fatema Mernissi, Syahrur, Abu Zayd and other feminists' group. In Indonesia, there were also few feminists that existed, for example, Nasaruddin Umar, Zaitunah Subhan, Mansour Fakih, MusdahMulia, and many other names.

Gender equality interpreters/exegetes make the principles of gender equality by referring to the verses of the Qur'an. It was then used as a basis for making gender-based interpretations on gender equality. This was based on a view that the mission of the Qur'an was revealed to uphold justice and to avoid discrimination, whether skin discrimination, gender, race and ethnicity (Nasaruddin Umar 1999).

\section{METHODOLOGY}

This study was using a qualitative method with the purpose to describe and analyze the principles of gender equality. Research with a qualitative approach was a study aimed to describe and analyze the phenomenon, events, social activities, attitudes, beliefs, perceptions, and thoughts of individuals and groups (Sukmadinata 2009). Qualitative methods as an inquiry procedure to produce descriptive data in the form of written or oral words of people and behavior that can be observed holistically (Moleong 2007).

This study was also being done by library research, which was by gathering the data that can only be obtained from library literature whether in the form of books, journals, and other scientific records (M. Iqbal 2002). The obtained data were analyzed using descriptive method. Besides that, this study was also used the critical approaches to correct the understanding that was considered inappropriate. According to Mujamil (2005), there were six stages in the method of criticism: a) seeing the object of criticism, b) evaluating criticism 
objects with guidance or footing, c) finding mistakes, d) finding alternative solutions, e) the alternative theory of the solution.

\section{FINDINGS}

In conducting the study of gender equality, feminists believe that in the days of the prophet SAW that practice of gender equality was already practiced. Not surprisingly, Qibtiyah (2014) dared say that the prophet Muhammad SAW was a feminist. It is also stated by Musdah, that patriarchal culture strengthened after the prophet Muhammad SAW died. Therefore, the urge Muslims to review the Quranic verses and hadith contextually and to avoid interpretations influenced by patriarchal culture (Nila Nurmila 2008).

Many feminists seek theological justification on the Quran and the hadith to support their belief in the struggle for gender equality. In addition, they elaborate on the basic concepts and principles of Islam in understanding gender equality. The common feminists make monotheism, caliphate, justice, worship, honor, friendship, brotherhood, freedom, and others as the basis of gender equality (Salahuddin 2016). Quranic verses that are often used by feminists as a theological justification in the study of gender are Al-Quran 33: 35, al-Hujrat 49: 13, Ali Imran 3: 195, Apocalypse 40: 40, al-Nisa 4: 124, al-Tawbah 9: 71 and so on. In addition, they also used the hadiths of the Holy Prophet to fit their idea of gender equality.

The above-mentioned verses and hadiths are generally understood by the feminists and do not interpret them with contextual and grammatical approaches. Besides being used as justification, it is also associated with verses or hadiths that are supposed to give preference to men. Thus, the verses or hadiths categorized as misogynistic are reviewed. According to Hamim Ilyas (2008) what is considered to be the truth of religious dogma that is textually embodied in revelation can be a social invention.

The verses or hadith which they consider to be misogynistic are also interpreted with a thematic approach and using the hermeneutic method. Amina Waudud (2001), a person who is very serious about fighting for gender equality, in her book entitled Quran and Woman: Rereading the Sacred Text from a Woman's Perspective, introduces "hermeneutic monotheism" as an analysis in understanding verses that she considers demeaning women. The same thing was done by other Muslim feminist figures, such as Musdah and Nasaruddin from Indonesia. Adherents to the ordinary hermeneutic method eliminate the sacredness of the transfigured text. Therefore, Askin (2004), a hermeneutic follower, said that the Koran as God's message has changed in the Arabic system. Then God's message was increasingly unclear and imprisoned if it was recorded in the form of Uthmani Manuscripts.

The tradition of interpretation of the hermeneutic method approach focuses on three aspects, namely text, context, and contextualization. The aspect of the text is how to understand the language that is in a text or something that is considered a text. When processing texts, the first concern of hermeneutics is the language aspect. The context aspect is also a basic understanding that is implanted in the hermeneutic method that the text does not stand alone, it is very dependent on the existence of contexts related to it, as well as aspects of the form as well as its contents. In summary, understanding the meaning of the text by ignoring the context that is around the text in question, will result in a reduction of the true meaning of the text. When the contextualization aspect is also a way to understand the text and context of the past, then try to understand it with a context that is in accordance with the present (Hidayat 2004).

Actually, the hermeneutic method originated from the Greek tradition, then developed as a method of interpretation of the Bible, then developed initially by theologians and philosophers as a method in general in the field of social sciences and humanities. Hermeneutics is not just an interpretation, but a separate method of interpretation or philosophy 
of interpretation that is very different from the method of interpretation of the Koran. In Christian circles, the current use of hermeneutics in Bible interpretation is very common, although it causes debate (Mazlan \& Yemen 2010). Therefore, the hermeneutic method applied by feminists in interpreting the Koran is not acceptable because basically it is used by Christians in interpreting the Bible. The Koran and the Bible are two very different books both in terms of their history and substance.

Feminists usually ignore the fact about the difference between the Koran and the Bible, but at the same time, they used the method of interpreting the Bible as a method of interpreting the Koran. The method of contextualization by ignoring the usual text is done in the biblical tradition because the Bible is indeed not a text of revelation. Biblical criticism has been long and developing in the West. More than among Christian intellectuals who admit that the Bible was not written directly through Jesus. According to them, some of the contents of the Bible are stories of events that Jesus experienced with Hawari (Jesus' faithful disciples). More than that, lately it was found that the contents of the Bible are letters from Christian pastors to their students (Asdar Yusuf 2016).

According to Hesselgrave and Rommen (2004) in Christian circles, almost no one believes that the Bible text is entirely God's revelation. The preservation of the Bible by God through the Greek Church, by making the Byzantine text the Textus Receptus (commonly accepted text), then translating it into English was known as the King James Version (1611). Therefore, the Bible King James Version is considered the only authoritative English translation

Muslim scholars such as al-Attas in Adian (2015) reject hermeneutics as a method of interpreting the Koran and he says that in interpretations there is no room for interpretations based on the subjective or based on the idea of historical relativism. According to him, the interpretation of the Koran is based on established science. Understanding the interpretation that has been established is that he tried to give meaning through real or external evidence (dilālah zāhirah) as a comparison of internal or hidden evidence (dilālah batiniyyah) contained in a deeper interpretation.

The principles of gender equality in the Qur'an are widely mentioned by Muslim feminists. One of them was by Nasaruddin Umar in his book entitled Perspektif Gender in the Qur'an. However, these principles were widely mentioned by other feminists too. These principles were used as the basis for making gender equality interpretations

\section{MEN AND WOMEN ARE SERVANT}

The purpose of man was created to worship and serve Allah S.W.T, as stated in Qur'an, Chapter al-Dhāriyāt 51: 56:

"And I did not create the jinn and mankind except to worship Me"

Nasaruddin (1999) stated that the position of man as a servant is the same between men and women. Both have the same opportunity to be piety servants. To achieve the degree of piety is not required to be gender differences, ethnic or ethnic groups. The Qur'an confirmed that the most ideal servant is the piety. Allah S.W.T said in Chapter al-Hujrāt 49: 13:

"O mankind, indeed We have created you from male and female and made you people and tribes that you may know one another. Indeed, the noblest of you in the sight of Allah is the most righteous of you. Indeed, Allah is Knowing and Acquainted"

According to Zaitunah (2015), the above verse explained the fundamental principles of Islamic teaching, which means the equality of human beings among the creatures of Allah S.W.T. The Qur'an as a scripture and changes agent teaches the doctrine of human equality, including gender equality and removes all the differences caused by gender, race, color, and 
ethnicity because humans are from the same type of ancestor. The human also was created to know each other and the most predominant among them, are the most righteous.

The feminist's point of view that both men and women were servants of Allah S.W.T, and it is not contradicted with the views from the Islamic scholars. Chapter al-Dhāriyat 51: 56 narrated the purpose of humankind which were to submit and worship Allah S.W.T is the obligatory duty of a servant. Ibn cAbbās mentions that jinn and humans are not created except for worship and submission to the command from Allah S.W.T. Imam al-Tabari (2000) viewed Ibn cAbbās as the most authorized opinion in understanding Chapter al-Dhāriyāt 51: 56. Similarly, with what had been mentioned by Imam al-Sacadi (2000), the purpose of the creation of jinn and humans, and the sending of the prophet is to prostrate and worship Allah S.W.T.

Implementing Chapter al-Dhariyat 51: 56 and al-Hujrāt 49: 13 as the basis of the principle of gender equality and denying man's "priority" in the field of muamalah, seemed to impose too much on the meaning of the verses. Whereas in Chapter al-Baqarah 2: 228, the male ranking is higher one degree than the female, al-Baqarah 2: 282, stated that the testimony of two women is equal to one man, meanwhile, al-Nisā' 4: 11 stated that men as the leader, protecting and responding to women and al-Nisā ' $4: 3$, stated the capability of men to polygamy. The "virtue" of men compared to the women described in the Qur'an, but that does not define men were more piety to Allah S.W.T. According to al-Zuhayli $(1418 \mathrm{H})$ "male preference" to women was defined by men's responsibilities towards women more than women's responsibilities toward men

\section{MEN AND WOMEN ARE THE CALIPHS}

The purpose of human-created was to be submissive servants, to serve Allah S.W.T, and also to be caliphs on the earth (khalā'if fì al-'ard). The position of human as caliph on the earth was mentioned in the Qur'an, Chapter al-Ancām 6: 165:

"And it is He who has made you successors upon the earth and has raised some of you above others in degrees [of rank] that He may try you through what He has given you. Indeed, your Lord is swift in penalty; but indeed, He is Forgiving and Merciful."

Allah's words in Chapter al-Baqarah 2: 30:

"And [mention, O Muhammad], when your Lord said to the angels, "Indeed, I will make upon the earth a successive authority." They said, "Will You place upon it one who causes corruption therein and sheds blood, while we declare Your praise and sanctify You?" Allah said, "Indeed, I know that which you do not know."

Nasaruddin (1999) stated that the word khalifah in the above two verses does not show any gender or ethnicity. Men and women have the same role as the caliphs, who will be accounted for the duties of the caliph on the earth, as they were responsible as the servants of Allah S.W.T.

Most exegetes do not discuss the above verse in the context of gender or type of gender. Al-Qurtubi (2003) explained the word khalaif was a plural form from the word khalifah and everyone who came from the previous generations, then they were called as caliph (successor).

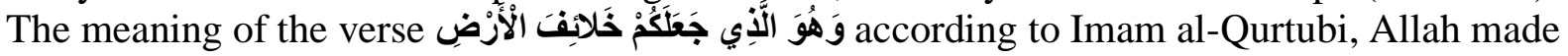
you the successor or as the successor of the previous generations. Ibn Kathir (1995) also

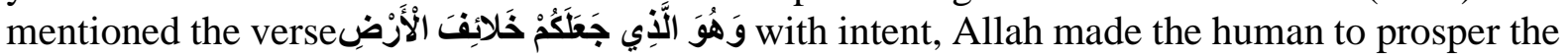
earth from one generation after one generation, and one time after time.

As for the word khalifah found in Chapter al-Baqarah 2:30, Imam al-Baghawi (1997) mentioned that the word khalifah in that verse was referred to the Prophet Adam. The mentioned of Adam's prophet as khalifah was because he came after (khalfa) jinn and in other opinion, this is because the Prophet Adam was different (yukhlifu) with other creatures. 
However, the most authentic opinion according to al-Baghawi, naming Adam as khalifah was because he was the "representative" of Allah on the earth to uphold the laws of Allah S.W.T and carry out the commandments from Allah S.W.T.

The broader view was mentioned by al-Shanqiti (1995) that the meaning of caliph in the Chapter al-Baqarah 2:30 has two forms of Islamic scholar interpretation. First, the caliph in the above verse was the Prophet Adam because he was the "representative" of Allah Almighty on the earth to carry out His commands. While the second opinion, the caliph of the singular form (mufrad) was understood in plural form. Therefore, the meaning of the word 'caliph' was the Prophet Adam and his descendants. Imam Ibn al-Qayyim (1993) mentioned that the khalifah's word in Chapter al-Baqarah 2:30 referred to the Prophet Adam but if the next verse was understood, then the khalifah was defined as the chosen people of Allah, the messenger of Allah, the prophets of Allah, the righteous servants (sālihin), the martyrs (shuhadā'), the scholars and they are more noble than the angels.

The opinions of exegetes on the interpretation of the meaning of khalifah do not define to one gender only. They emphasized the role of a caliph on the earth. Although it may be understood that the tendency of clarification of Islamic scholars to the khalifah leads to men, as being explained by Ibn al-Qayyim. This was contradicted to the feminists who set the two verses above as the principle of gender equality which implied that both men and women were the khalifah. The significance of these feminists seemed to impose too much on the two verses as the basis of the principle of gender equality.

\section{MEN AND WOMEN ARE ACCEPTING THE COVENANT}

Both men and women have accepted the covenant since in the womb with Allah Almighty. It was well known that before the baby was born, it first receives an agreement from Allah Almighty. Allah's word in Chapter al-Acraf 7: 172:

"And [mention] when your Lord took from the children of Adam - from their loins their descendants and made them testify of themselves, [saying to them], "Am I not your Lord?" They said, "Yes, we have testified." [This] - Lest you should say on the Day of Resurrection, "Indeed, we were of this unaware."

According to Nasaruddin (1999), the word بَنْي عَادَدَ in the above verse referred to all the children of Adam, without distinguishing gender, ethnicity, and skin color. In the Qur'an, no one had ever found a verse that points to a person's priorities because of gender or ethnic origin and race. In the Islamic religion, individual responsibility had been existed since in the womb of the mother. Since the beginning of human existence in Islam, there is no gender discrimination. Both men and women were admitted to the existence of Allah Almighty. Muslim women's dignity in Islam emerged since birth, this is because in the beginning they have never been given a burden of "inherited sin" as in Judaism and Christianity. The Qur'an had a positive outlook on humans by asserting that Allah glorified all the offspring of Adam.

According to Chapter al-A'raf 7: 172, every human being got a question since they were in the womb and it was not distinguished between men and women. All human were acknowledged and established Allah Almighty as God and the creator. However, after they were born there was a change over their testimony and followed the wrong faith (al-Sac ${ }^{c}$ i: 2000). The covenant and recognition of every human being had been accepted the oneness of Allah Almighty as God and the creator since in the womb and this was the basis of humanity in worshipping Allah Almighty. This matter was applied to every human being, without gender discrimination.

The verse stated on the covenant since in the womb was taken by feminists as the principle of gender equality based on the reason that at the beginning of human creation there 
was no discrimination between men and women. Their views were seemed to imposing the meaning of the verse as the basis of the principle of gender equality, as Chapter al-A'rāf 7: 172 generally had discussed on the creation of man and how to obey Allah Almighty while in the womb. In obeying Allah Almighty there had been no discrimination, and the tauhid is a duty for every human being, regardless of any gender. This reasoning was contradicted to the roles and responsibilities of men and women in daily life. Islam had organized the duties of men and women, in accordance with their respective natures, without the intention of lowering one's gender.

\section{ADAM AND EVE INVOLVED IN THE INFRINGEMENT OF HEAVEN}

Among the feminists, they said that all the verses that mentioned about the cosmic drama (the story of Adam and Eve) stated that they were both involved. This event can be witnessed by using the pronouns for two people (ها), which referred to Adam and Eve. There were few verses that told about the involvement of both Adam and Eve in the infringement of heaven. The first verse was from Chapter of al-Baqarah 2:35 which stated that Adam and Eve were both created by Allah Almighty in heaven and they enjoyed the facilities in heaven. The second verse stated from Chapter al-A'raf 7:20 which told that Adam and Eve were getting the same seduction from the devil to eat the khuldi (forbidden fruit) in the heaven, and the third verse from Chapter al-A'raf 7:22 told about Adam and Eve both ate the khuldi and both were received the same consequence which was, being removed from heaven and going down to the earth. The last verse from Chapter al-A'rāf 7:23 stated that Adam and Eve were both seek forgiveness from Allah and received forgiveness equally.

According to Nasaruddin (1999), the statements contained in the above verses differ from the statements in the Bible (Torah and the Gospel) which were imposed heavier mistakes on Eve. The above verses also mentioned that Adam and Eve were together as the doer and being responsible for their actions. Thus, the Qur'an never underestimated Eve as a woman.

The above verses were provided the assertions that Adam and Eve through the same process of creation until they were brought down to the earth together but if we studied the above verses in-depth, then it does not seem to be related to gender equality issues. In this case, Nasaruddin (1999) was seemed to define gender with a concept used to identify the differences between men and women from the socio-cultural side. The above verses generally were narrated the history of Adam and Eve; from creation to exclusion from heaven and finally live on the earth. There were few things that they were did together for example, they both were the creatures, got seduction, ate khuldi and asked for forgiveness. All the examples were not referred to or showed any gender as defined. The verses only narrated the history of Adam and Eve, not the assessment of Adam and Eve from the social-cultural side. Nasaruddin, known as a gender equality successor, was imposed on the above verses as the basis of the principle of gender equality. It was well known, as being said by Siti Muslikhati (2004) stated that the feminists were always trying to define or impose meaning on the verses to their respective ideology.

\section{BOTH MEN AND WOMEN HAVE SAME POTENTIAL}

The feminists thought that the opportunity to achieve maximum performance was no difference between men and women. This was being used as one of the principles of gender equality. The word from Allah Almighty in Chapter al-Nahl 16:97: 
"Whoever does righteousness, whether male or female, while he is a believer - We will surely cause him to live a good life, and We will surely give them their reward [in the Hereafter] according to the best of what they used to do."

The feminists' point of view of the above verse implied the ideal concept of gender equality and asserted that the individual's performance, whether in the spiritual or professional career, should not be monopolized by one gender. Both men and women had the opportunity to achieve the highest achievement.

Nasaruddin (1999) stated that one of the goals of the Qur'an was the realization of justice in a society which means, Qur'anic justice in all forms of human life, whether individual or as a member of society. Qur'an does not allow oppression in the form of different gender, ethnic groups, skin color, ethnicity, and belief. When there was a repressive interpretation or infringement of humanitarian values, the understanding and interpretation of Qur'an verses must be reviewed.

On the pillars, Islam had never discriminated between men and women in the performance of worshipping Allah Almighty. Everyone who does good deeds, whether male or female, with the condition of having the right faiths in Allah Almighty, will be given a good life and later in the Hereafter will be received a reward from Allah Almighty, according to his/her charitable deeds without deduction. The above verses were narrated on the reward of human virtues, both men and women. In the case of good deeds or opportunities to be closer to Allah Almighty, Islam had never distinguished between men and women.

However, Islam remained in the principle of giving priority to men without intimidating women. According to al-Zuhayli (1418 AH), men are bestowed on women from two sides. First, of physical strength, men have stronger bodies and minds compared to women. Therefore, only men who received the prophetic leaflet were entitled to be the highest leader, the $q \bar{a} d i$ (decision-makers), perform the eminences, such as azan, iqamah, sermons, Friday prayers, jihad, divorced rights, polygamy, received testimony in criminal cases and hudud, and get more share of the inheritance. Secondly from the side of responsibility, men were obliged to give alimony to his wife and his closest relatives and obliged to give a dowry to his wife in honor and glory of women. As for these above reasons, both men and women had the same rights and obligations.

It can not be denied that there were women who had performed in many fields, even better than men. However, this was still considered something that is $n \bar{a} d i r$ (rarely happened). Islam had been regulated its shariah based on reality, not based on special cases, which were still considered rare. The ruling of Allah Almighty took men more than women in some matters to have the value of justice if being understood comprehensively. Indeed, Allah Almighty will not degrade women over men. Allah as a human creator knows the best and fairer to His servants (Siti Rabi'ah 1999).

\section{CONCLUSION}

The Muslim feminists had been defined by several Qur'anic verses as the principles of gender equality. Furthermore, the verses had been used as the basis for interpreting Qur'anic verses in their form of ideology. This movement was based on the opinion that was clarified many classical interpretations were gender-biased and regarded women as a second-class society. Men were viewed as superior creatures while women were viewed as inferior.

The principles of gender equality created by the feminists seem to impose the meaning of the Qur'anic verses to support their ideology. The verses of the Qur'an as the basis of gender equality, basically do not discuss men's and women's relationships. Accordingly, the verses should be understood in proportion without having to impose their meaning. 


\section{REFERENCES}

Alimatul Qibtiyah dan Muh. Isnanto (2013) Dinamika Discours Gender di UIN Sunan Kalijaga Yogyakarta. Yogyakarta: PSW UINSUKA.

Adian Husaini (2015) Problematika Tafsir Feminis: Studi Kritis Konsep Kesetaraan Gender. Al-Tahrir: 15 (2) 13-23.

Aksin Wijaya (2004) Menggugat Otentitas Wahyu Tuhan: Kritik Atas Nalar Tafsir Gender. Yogyakarta: Safiria Insania Press.

Amina Wadud (1992) Qur'an and Woman: Rereading the Sacred Text from a Woman's Perspective. Kuala Lumpur: Penerbit Fajar Bakti.

Andi Asdar Yusuf (2016) Metode Bible Dalam Pemaknaan al-Quran: Kajian Kritis Terhadap Pandangan Orientalis. Hunafa: Jurnal Studia Islamika:13 (1) 1-11.

David J. Hesselgrave dan Edward Rommen (2004) Kontekstualisasi: Makna, Metode dan Model. Jakarta: BPK Gunung Mulia.

al-Baghawi,Muhyi al-Sunnah Abū al-Husayn ibn $\mathrm{Mas}^{\mathrm{c}} \bar{u} d$ (1997) $M a^{c} \bar{a} l i m$ al-Tanzil fi Tafsir al-Qurān. Beirut:DārIhyā' al-Turāth al- ${ }^{\mathrm{c}}$ Arabi.

al-Dimashqi, Abu al-Fidā' Ismā̄il bin 'Umar (1999) Tafsir al-Qurān al-ćAzìm. t.tp: Dār alTayyibah.

Friedrich Kluge \& Frederick Lutz (2008) English Etymology.Charleston, South Carolina: BiblioBazaar.

Hamim Ilyas (2008) Wanita Tertindas: Kajian Hadis-hadis Misoginis. Yogyakarta: PSW Sunan Kalijaga.

Henri Shalahuddin (2016) Wacana Kesetaraan Gender Dalam Pemikiran Islam Di Institusi Pengajian Tinggi Islam Negeri Di Indonesia: Kajian Kes Di Universitas Islam Negerisunan Kalijaga Yogyakarta. Unpublished Ph.D thesis, Universiti Malaya, Kuala Lumpur.

John M. Echols \& Hassan Shadily (1983) KamusInggeris Indonesia. Jakarta: Gramedia.

al-Jauziyyah, Muhammad ibn Abi al-Bakr ibnQayyim. t.th.Miftah alSacādahwaManshūrWilāyah al-' $I l m w a$ al-'Irādah. Beirut:Dār al-Kutub al-'Ilmiyyah.

Kadarusman (2005) Agama, Relasi Gender danFeminisme.Jogjakarta:Wacana.

Komaruddin Hidayat (2004) Menafsirkan Kehendak Tuhan. Jakarta: Teraju.

Lexy J. Moleong (2009) Metodologi Penelitian Kualitatif. Bandung: PT. Remaja Rosdakarya.

M. Iqbal Hasan (2002) Pokok-PokokMateriMetodologiPenelitiandanAplikasinya. Bogor. Ghalia.

Mazlan Ibrahim dan Achmad Yaman. 2010. Penyelewengan Tafsir al-Quran: Kritikan Terhadap Buku Fiqih Lintas Agama. Bangi: Penerbit UKM.

M. Lips (1993) Sex \& Gender: an Introduction. California: Mayfield Publishing Company.

Mujamil Qomar (2005) Epistimologi Pendidikan Islam: Dari Metode Rasional Hingga Metode Kritik. Jakarta: Airlangga.

Nila Nurmila (2008) Modul Studi Islam dan Jender: Pedoman Mata Kuliah Studi Islam dan Jender. Jakarta: PSW UIN Jakarta.

Nasaruddin Umar (1999) ArgumenKesetaraan Gender Persfektik al-Quran. Jakarta: Paramadina.

al-Qurtubi, Muhammad ibn Ahmad Shamsuddin (2003) Al-JāmicliAhkām al-Qurān.Riyād: DārcAlam al-Kutub.

Siti MusdahMulia (2011) MuslimahSejati. Bandung: Marja.

Siti MusdahMulia (2014) MuslimahReformis. Bandung: Mizan.

Sukmadinata (2009) Metode penelitian pendidikan. Bandung: RemajaRosdakarya. 
Siti Muslikhati (2004) Femenisme Dam PemberdayaanPerempuanDalamTimbangan Islam. Jakarta: GemaInsani.

Siti Rabi'ahSarnap (1999) Wanita dalam al-Quran dan al-Sunnah. Johor: Percetakan Nasional Malaysia Berhad.

al-Sa ${ }^{\mathrm{c}} \mathrm{di}^{\mathrm{C}}$ Abdurrahmān ibn Nāsir (2000) Taysir al-Karim al-Rahmān fi Tafsir Kalām alMannān. t.tp: Mu'assas al-Risālah.

al-Shanqiti, Muhammad al-Amin ibn Muhammad al-Mukhtār (1995) 'Adwā'u al-Bayān fi 'idāh al-Qurān bi al-Qurān. Beirut:Dār al-Fikr.

al-Tabari, Muhammad ibn Jarir (2000) Jāmicfi Tafsir al-Qurān. t.tp: DārHajr.

Walter W. Skeat (1993) The Concise Dictionary of English Etymology. Hertfordshire, UK:Wordsworth Editions.

Zaitunah Subhan (2015) Al-Quran danPerempuanMenujuKesetaraan Gender DalamPenafsiran. Jakarta: Pranadamedia Group.

al-Zuhaili,Wahbah ibn Mustafā (1418 H) al-Munir.Damshiq: Dār al-Fikr al-Mu'āsr.

\section{ABOUT THE AUTHORS}

Karimuddin Nasution graduate Doctor of Philosophy in the field of al-Quran and Sunnah from National University of Malaysia. Master in the field of al-Quran and Sunnah and also from National University of Malaysia. Meanwhile, BA is majoring in Tafsir Hadith from State Islamic University of Sultan Syarif Kasim, Riau (UIN SUSKA).

Mohd Faizulamri bin Mohd Saad, is a Senior Lecturer at the Center for the Study of al-Quran and al-Sunnah, Faculty of Islamic Studies, National University of Malaysia. Graduated with Doctor of Philosophy in the field of Qira'at and Tafsir (National University of Malaysia), Master in the field of Qira'at, Tafsir and Fiqh (National University of Malaysia) and BA in the field of al-Quran and Qiraat (Maahad Qiraat al-Azhar, Shoubra, Egypt). 